\title{
A Marketable Leadership Strategy in Service Business; Case Study at KBIHU Nurul Haramain Kraksaan Probolinggo
}

\author{
Moh. Rifa' I, ${ }^{1}$ Mukhlisin Saad, ${ }^{2}$ Lutfiyatul Hasanah, ${ }^{3}$ Rasyidah Nur Aisyah ${ }^{4}$ \\ ${ }^{1}$ Nurul Jadid University Probolinggo, ${ }^{2}$ UIN Sunan Ampel Surabaya, ${ }^{3}$ Sekolah Tinggi Ekonomi \\ dan Bisnis Islam Badri Mashduqi Probolinggo, ${ }^{4}$ PGRI Wiranegara University) \\ Imohrifaiahmad@unuja.ac.id, ${ }^{2}$ mukhlisin.saad@uinsby.ac.id, \\ ${ }^{3}$ lutfiyatulhasanah@stebibama.ac.id, ${ }^{4}$ ocicyah@gmail.com
}

\begin{abstract}
Realizing marketable guidance in the pilgrimage leadership is not easy to put into practice. It takes a leadership strategy that are has positive implications for each congregation that he leads, so that it has an impact on increasing the volume of pilgrims in every year. This research used a qualitative approach, with a descriptive type. The research data source was obtained from KBIHU Nurul Haramain by purposive sampling and snowball sampling model. The data collection technique was carried out by using observation, interviews, and documentation. While the technical data analysis was by collecting data, reducing data, and drawing conclusions. The validity of the data used a triangulation model. The research results explained that the marketable leadership strategies carried out by the kyai, are: service strategies that are easy to understand by implementing Hajj exercises or rituals 12 times in 1 year and in collaboration, the Hajj practice directly led by Kyai and professionals, direct guidance from home to the holy lands of Makkah and Medina, arranging rituals scheduled as needed the knowledge systematically. Strategies of figures that appear in the Kyai consist of namely friendly service, and excellent facilitation for the congregation from in the country to the holy land.
\end{abstract}

Keywords: leadership strategy, Guidance of kyai, Increasing the volume of the pilgrims.

\begin{abstract}
Abstrak
Mewujudkan tuntunan yang dapat dipasarkan dalam kepemimpinan haji tidaklah mudah untuk dipraktikkan. Dibutuhkan strategi kepemimpinan yang berimplikasi positif pada setiap jemaah yang dipimpinnya sehingga berdampak pada peningkatan volume jemaah haji setiap tahunnya. Penelitian ini menggunakan pendekatan kualitatif, dengan tipe deskriptif. Sumber data penelitian diperoleh dari KBIHU Nurul Haramain dengan metode purposive sampling dan model snowball sampling. Teknik pengumpulan data dilakukan dengan observasi, wawancara, dan dokumentasi. Sedangkan teknis analisis datanya adalah dengan mengumpulkan data, mereduksi data, dan menarik kesimpulan. Validitas data menggunakan model triangulasi. Hasil penelitian menjelaskan bahwa strategi kepemimpinan marketable yang dilakukan oleh kyai, yaitu: strategi pelayanan yang mudah dipahami dengan melaksanakan latihan atau ritual haji 12 kali dalam 1 tahun dan secara gotong royong, pengamalan haji langsung dipimpin oleh Kyai dan profesional, langsung bimbingan dari rumah ke tanah suci Mekkah dan Madinah, mengatur ritual yang dijadwalkan sesuai kebutuhan ilmu secara sistematis. Strategi tokoh yang muncul dalam diri Kyai terdiri dari pelayanan yang ramah, dan pendampingan yang prima bagi jamaah dari dalam negeri hingga ke tanah suci.
\end{abstract}

Kata Kunci: strategi kepemimpinan, Bimbingan kyai, Meningkatkan volume jamaah. 


\section{Introduction}

In fact, hajj is a personal approach to Allah SWT by performing ihram, thawwaf, wukuf, sa'i, tahallul, and others. This worship becomes a media for moeslems to perform worship to the House and the holy land which is performed every year. Hajj is the fifth pillar of Islam that is obligatory by Allah SWT for those who are able to perform it, that is to have the ability to cost as well as physically and spiritually healthy to perform the worship.

Muslims who are going to perform the hajj pilgrimage are required to be physically and financially capable, ${ }^{1}$ and the Indonesian people constitute the largest number of people in the world who perform the pilgrimage every year, according to the decision of the minister of religion regarding the 2020 hajj quota. ${ }^{2}$ However, due to the limited quota for performing the pilgrimage to the Holy Land, it is not possible to do it immediately. ${ }^{3}$ The obligation of Hajj and Umrah is only once in a lifetime, if it is fulfilled again, it is punished as sunnah.

The scholars' interpreted the meaning of istitha'ah which means physically and mentally healthy, able to travel, have sufficient supplies, are safe on the move, and are safe in the holy land. However, the meaning of istitha'ah varies according to the conditions of each person, and Allah SWT still pays attention to people who are unable to travel to Baitullah. ${ }^{4}$

Due to the urgency of the implementation of this Hajj pilgrimage for Muslims, the guidance requires excellent service by individuals or Hajj guidance groups such as the KBIHU (Hajj and Umrah Guidance Group), especially in terms of leadership, so that satisfaction for the congregation appears and service is a priority concern. The guidance leadership strategy emphasizes how the organization needs to work persistently and act well in dealing with all forms of congregational needs and competitive guidance provided by other guidance

${ }^{1}$ Zainur Ridho, 'Pengelolaan Keungan Dana Haji Di Masa Pandemi Covid-19', Haramain, 01.01 (2021), 1-27.

2 Kementerian Agama RI, 'Keputusan Menteri Agama Tentang Penetapan Kouta Haji 2020.Pdf' (Jakarta, 2020), pp. 01-06.

${ }^{3}$ M. Sabiq Al Hadi, 'Rekonstruksi Pemahaman Yang Keliru Tentang Kewajiban Dan Keutamaan Haji Dan Umroh', Al-Iqtishod: Jurnal Ekonomi Dan Bisnis Islam, 01.01, 65-84.

${ }^{4}$ Muhammad Yusuf, ‘Haji Dalam Al-Qur'an, Hadis Dan Pengalaman Muslim', 2008. 
groups. Of course, this is done in order to increase congregational satisfaction through improving operating attitudes, leadership and management. ${ }^{5}$

The problem with the KBIHU Hajj guidance in terms of the current market is that it is faced with the many competition for Hajj and Umrah guidance groups that exist in the archipelago. Competition is the efforts of two parties, either companies or individuals, each of which is active in obtaining orders, by offering programs that are profitable for businessmen with guidance that are tailored to the needs and abilities of the prospective congregation. ${ }^{6}$ In fact, not all guidance group leadership can provide satisfactory services to the congregation.

In contrast to the results of a survey conducted by researchers, that KBIHU Nurul Haramain was able to provide good service and satisfy the congregation so that it has implications for the marketable aspect. Services that have implications for the satisfaction of pilgrims are emphasized in the strong sense that the guidance group must recognize that the characteristics of the pilgrims are different in defining services, the quality of services depends on the quality of services performed. ${ }^{7}$

The problems that occur in the Hajj guidance group are issues of leadership and matters related to the success of a guidance that will be carried out and facilitate the process of achieving targets, both in the fields of service, guidance, training and so on, so that what the congregation aspires to do and KBIHU in performing the haj pilgrimage can be achieved. ${ }^{8}$ In addition to his strengths, he is led by a Kyai.

The existence of the Kyai in the guidance of this pilgrimage is an inseparable unit because the Kyai figure is very dominant in determining all

5 Sulaiman Sulaiman, 'Kepuasan Jamaah Haji Terhadap Pelayanan KBH Di Kabupaten Jepara', Analisa, 21.1 (2014), 51 <https://doi.org/10.18784/analisa.v21i1.27〉.

${ }^{6}$ Vanesha Pitoy and others, 'Analisis Strategi Bersaing Dalam Persaingan Usaha Bisnis Document Solution ( Studi Kasus Pada Pt . Astragraphia , Tbk Manado )’, 16.03 (2016), 302-12.

${ }^{7}$ Moh. \& Abd. Adhiem Rifa'i, Manajemen Koperasi Ritel Pondok Pesantren (Seni Tata Kelola Praktis Koperasi Ritel), ed. by Moh. Rifa'i, First Edit (Kraksaan Probolinggo: CV. Mandiri Probolinggo, 2018) <https://doi.org/9786025060182>.

8 Dzul Kifli, 'Manajemen Pelayanan Jamaah Haji Dan Umrah Pt. Patuna Tour Dan Travel', Skripsi, 2010, 1-90.

Tribakti: Jurnal Pemikiran Keislaman Volume 32, Nomor 1, Juli 2021 
policies, management and development of the Institution he leads ${ }^{9}$ including matters relating to the guidance of the pilgrimage for the congregation. In this case, the Kyai used a variety of different strategies, styles or types of leadership. In fact, one view suggests that in leading, Kyai does not display specific leadership patterns or styles that apply in all situations, but what happens is conditional. ${ }^{10}$

As the concept of leadership in the pilgrimage service which uses management consisting of planning, organizing, directing, and monitoring. All of this is of course an obligation for the manager to be truly active and focus on identifying the source of the problems faced with the problem of not many prospective pilgrims joining the organization. Many things need to be considered in addition to the service management mentioned above.

According to Crainer perspective, there are more than 400 definitions of leadership. Of the many definitions of leadership, some say leadership is an activity to influence others. ${ }^{11}$ The leadership of the Kyai is a process to influence group activities both at the Islamic boarding school and its development institutions. ${ }^{12}$ Leadership is the ability to obtain agreement on common goals. Leadership is an attempt to direct others to achieve certain goals. ${ }^{13}$ How the leader and his group can behave in various leadership structures, cultures, and their environment is the ultimate target of leadership intentions. ${ }^{14}$

KBIHU Nurul Haramain is located on Jl. Ir. Juanda No. 370 RT. 01 RW. 06 Patokan Village, Kraksaan District, Probolinggo Regency 67282 have a good

${ }^{9}$ Mia Kurniati, Miftahus Surur, and Ahmad Hafas Rasyidi, 'Peran Kepemimpinan Kyai Dalam Mendidik Dan Membentuk Karakter Santri Yang Siap Mengabdi Kepada Masyarakat', Al-Bayan: Jurnal Ilmu Al-Qur'an Dan Hadist, 2.2 (2019), 194-203 <https://doi.org/10.35132/albayan.v2i2.80>.

${ }^{10}$ Lukman Al-karim, 'Gaya Kepemimpinan Kyai Lukman Al-Karim Dalam Pengembangan Lembaga Pendidikan Islam ( Studi Kasus Di Pondok Pesantren Bahrul Maghfiroh Malang )’, 15 (2015), 497-518.

${ }^{11}$ Oleh Euis, 'Kepemimpinan Yang Efektif Dan Perubahan Organisasi Oleh : Euis Soliha Dan Hersugondo Fakultas Ekonomi Universitas Stikubank Semarang', Fokus Ekonomi, 7.2 (2008), 83-93.

${ }^{12}$ Zaenal Arifin and Moh. Turmudi, 'Character of Education in Pesantren Perspective: Study Of Various Methods of Educational Character at Pesantren In Indonesia Zaenal Arifin 1, Moh. Turmudi 2 1', Tribakti: Jurnal Pemikiran Keislaman, 30 (2019), 335-48.

${ }^{13}$ Farhad Nezhad Haj Ali Irani and others, 'Issn 1412 - 8683 29', Procedia - Social and Behavioral Sciences, IV.2 (2017), 29-38.

${ }^{14}$ Ridwan Nurfalah Nurfalah, Syamsuddin RS, and Arif Rahman, 'Strategi Pimpinan Dalam Optimalisasi Rekrutmen Jamaah Haji', Tadbir: Jurnal Manajemen Dakwah, 2.3 (2017), 309-28 <https://doi.org/10.15575/tadbir.v2i3.567>. 
achievement to be researched in order to study his leadership strategy. The volume of congregants in each year is always increasing. Based on the data, it shows that in 2017 there were 384 worshipers, in 2018 there were 391 worshipers, and in 2019 there were 410 worshipers, in 2020 there were 415 worshipers, but it is still postponed due to the COVID-19 pandemic. To proving that there are increase in the volume of pilgrims at KBIHU Nurul Haramain Probolinggo, which many congregations believe in the work of good leadership in guiding the congregation to successfully carry out the Hajj pilgrimage to Baitullah.

In order to make it easier for readers to understand this data, the researcher illustrated it in the form of a flowchart, as follows:

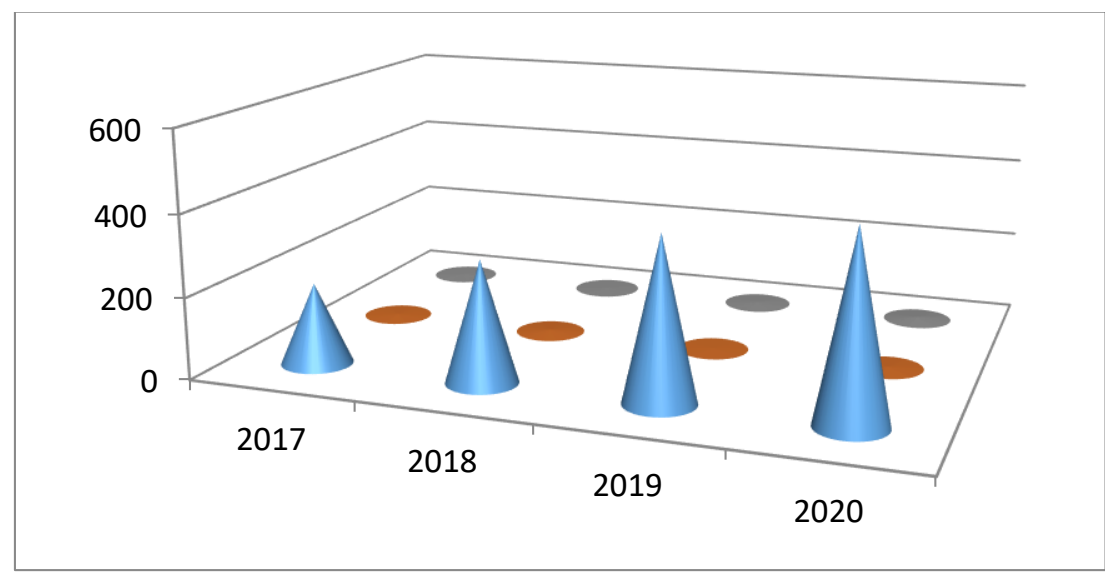

Figure 1. Data of the Nurul Haramain KBIHU Hajj Pilgrims in the Last 3 Years.

So, based on the data above, the researcher is very interested in studying the aspects of Hajj guidance in more depth, which are directly guided within the scope of Kyai's leadership with the title "a marketable leadership strategy in service business."

\section{Method}

This method used descriptive qualitative to examine the research in detail. The research data was obtained from the highest leader of KBIHU Nurul Haramain (Purpose sampling) but also still considering the snowball sampling model for the perfection of the required data. The data collection techniques were carried out by technical in-depth interviews, participant observation techniques, 
and by documentation techniques. While the technical data analysis is done by collecting data, reducing data, displaying data, and drawing conclusions. The validity of the data used triangulation, namely data testing between data sources, methods, data collection techniques, and theory. ${ }^{15}$ This research was carried out by considering the extension of time if necessary, so that truly authentic data were obtained. The grand theory used is based on the findings of Abdul Aziz alBarqy according of leadership strategies about assertiveness, courtesy, intimacy, togetherness, and equality role.

\section{Results And Discussion}

\section{Easy-to-Understand Guidance}

Based on the findings in the study, it explains the findings that in the leadership of the pilgrims, the Kyai provides guidance that is easily understood by the pilgrims who join his guidance group. The priority of organizing the Hajj guidance program is indirectly carried out in various best ways and with excellent service so that the pilgrims are able to carry out the pilgrimage as well as possible in order to achieve the mabrur hajj. The quality human resources are of particular concern to Kyai in guiding pilgrims, so that they are empowered to improve the quality of themselves and the quality of social life universally. ${ }^{16}$

The ease and understanding of the guidance by the Kyai for the pilgrims is carried out in the following way:

1. Kyai implements the practice the rituals of Hajj 12 times a year, even more because there is still guidance for team leaders and group leaders 2 times specifically to equip these leaders in providing services to their members both during the trip and during, they stay in holy land of Makkah and Medina. ${ }^{17}$ This has been determined in the schedule that has been compiled and becomes the guidance program for the Hajj rituals of KBIHU Nurul

15 Wahyu Dwi Irawan, 'ANALISIS KUALITAS PELAYANAN DALAM UPAYA MENINGKATKAN LOYALITAS PELANGGAN CV. CAHAYA EMPAT PILAR BANJARMASIN' (Universitas Islam Kalimantan MAB, 2020).

35.

${ }^{16}$ Alexander Velasquez-Valencia and others, 'No Titleفسرس', Interciencia, 489.20 (2018), 313-

${ }^{17}$ Moh \& Dela Maghfirah Kamila Rifa'i. 
Haramain. This strategy provides an illustration of the implementation of the pilgrimage to prospective pilgrims specifically and provides insights on how to anticipate problems that arise in the implementation of the pilgrimage. ${ }^{18}$ Unlike what Abdul Aziz Al-Barqy conveyed, the findings in this study really add to and enhance it in order to motivate the congregation to join the guidance group led by Kyai. The existence of the guidance program has positive implications for prospective pilgrims to join the Hajj guidance. As for assertiveness, courtesy, intimacy, togetherness, and equality in positions which are used as strategies for leadership, none of them are related to the intensive program implementation carried out by the Kyai as a marketable leadership strategy. So, the intensity of the manasik program is an effective strategy for this which makes a big contribution that the pilgrims get an easy-to-understand explanation to be implemented both in the homeland and in the holy lands of Mecca and Medina. ${ }^{19}$

2. In cooperate with experienced and professional travelers meet the needs of the communities to go for Hajj. This collaboration is done not only for the needs of the pilgrims' departure, but also for the needs of professionalism in guidance starting from the homeland to the holy lands of Mecca and Medina. Of course, the relevance is in their respective fields in presenting material to the congregation. The cooperation competencies used in guidance activities include politeness listening to other people talking and speaking only after other people have finished talking, interrupting politely, appreciating other people's ideas, catching other people's ideas appropriately before expressing disagreement, the most important thing is to support every participation of people invited to work together meets the needs of the guidance group. ${ }^{20}$ In this case, there are some aspects of

18 Sandoz do Brasil Ind. Farm. Ltda., 'Strategi Peningkatan Pelayanan Jamaah Haji KBIH Muhammadiyah Palembang', Journal of Chemical Information and Modeling, 53.9 (2015), 1689-99.

${ }^{19}$ Inayah Swasti Ratih, 'Strategi Bisnis Syariah Dalam Menghadapi Pandemi Covid-19', IZZI, 1.1 (2021), 1-18.

${ }^{20}$ Ika Ari Pratiwi, Sekar Dwi Ardianti, and Moh. Kanzunnudin, 'Peningkatan Kemampuan Kerjasama Melalui Model Project Based Learning (Pjbl) Berbantuan Metode Edutainment Pada Mata Tribakti: Jurnal Pemikiran Keislaman Volume 32, Nomor 1, Juli 2021 
leadership strategies consisting of assertiveness, courtesy, togetherness, familiarity, and equalization of positions in carrying out strategic steps that have an impact on people's motivation to use the guidance services offered. ${ }^{21}$ The theme of cooperation, as the findings of the researcher, specifically has nothing to do with the leadership strategy presented by Abdul Aziz al-Barqy, but the indicators and behaviors in its implementation are closely related to the strategy put forward. In essence, this finding are more complementary to the fact that these indicators are carried out in the form of cooperation with various parties so that marketable results emerge for the KBIHU they lead. ${ }^{22}$ This aspect contributes to the knowledge and understanding of the congregation that the Kyai provides guidance that is easy for the pilgrims to understand, due to the collaboration with various professional parties related to the implementation of the haj pilgrimage.

3. Performing the pilgrimage practice directly led by the Kyai and the professionals involved as guides. The kyai made this direct practice a marketable leadership strategy for the KBIHU he led. The direct practice was not put forward by Abdul Aziz al-Barqy in his research findings, but the nuances of togetherness between the Kyai and the congregation are in the implementation of the practice of Hajj rituals directly or indirectly. These strategies are provision for the congregation to understand the guidance provided by the Kyai in his leadership in the country and during the Hajj pilgrimage in Saudi Arabia. ${ }^{23}$ It is the same as the previous point that the findings in this study complete a common thread that has not been revealed even though some of the indicators have been realized. This finding explains specifically that togetherness needs to be displayed in a specific activity, that is, it can occur in leadership practices in general and

Pelajaran Ilmu Pengetahuan Sosial', Refleksi Edukatika: Jurnal Ilmiah Kependidikan, 8.2 (2018) <https://doi.org/10.24176/re.v8i2.2357>.

${ }^{21}$ Nurfalah, RS, and Rahman.

${ }^{22}$ Moh \& Dela Maghfirah Kamila Rifa'i.

${ }^{23}$ Pusti Lestari, Dadang Kuswana, and Yuliani Yuliani, 'Strategi Pelayanan Prima Kelompok Bimbingan Ibadah Haji Terhadap Calon Jamaah Dalam Meningkatkan Bimbingan Kualitas Ibadah Haji’, Tadbir: Jurnal Manajemen Dakwah, 1.3 (2016), 258-74 <https://doi.org/10.15575/tadbir.v1i3.139>. 
Haj pilgrimage in particular. The strengths and weaknesses of this practice will be revealed and that is where the congregation acknowledges their condition, but can directly make comfortable improvements due to the situation and the nuances of togetherness. ${ }^{24}$ The point is there is no shame and haste because they are considered not understanding, but everything appears with flexible conditions.

4. Explaining specifically what has been stated indirectly in the previous points, that the Kyai's leadership strategy in guiding the pilgrims took place from home to the holy land of Makkah and Medina. This strategy makes it easy to understand the guidance given by the Kyai to the pilgrims. Each KBIHU certainly implements a different management of guidance from one another, even though it is basically the same, namely guiding prospective pilgrims so that the Haj procession in the Haram land can be carried out smoothly and in accordance with Islamic sharia so that all worship can be declared valid and mabrur. ${ }^{25}$ The leadership strategy of pilgrims like this has implications for the motivation of the prospective pilgrims in a circular manner from time to time which is conveyed through impressions that are revealed from one congregation to another and to others so that it contributes positively to the market of KBIHU Nurul Haramain which is led by Kyai. ${ }^{26}$ This finding did not explain by Abdul Aziz al-Barqy in his findings, so it is a specific finding that explains the previous findings. How togetherness, courtesy, mutuality, and assertiveness occur in the conditions of the pilgrimage practice given to the congregation in starting the homeland to holy lands of Mecca and Medina. This is quite interest and provides an advantage between both parties (Win-win solution). Then back to the findings in this study, that a leadership strategy makes it easier for

${ }^{24}$ Sulaiman.

${ }^{25}$ Widyarini, 'Manajemen Kelompok Bimbingan Ibadah Haji ( KBIH )', Jurnal Ekonomi Dan Bisnis Islam, EKSIBISI, VII.2 (2013), 165-66.

${ }^{26}$ Moh. Rifa'i, Community Empowerment (Pemberdayaan Masyarakat Dalam Meningkatkan Mutu Pendidikan), ed. by Moh. Rifa'i, 1st edn (Kraksaan Probolinggo: CV. Mandiri Probolinggo, 2017). Tribakti: Jurnal Pemikiran Keislaman Volume 32, Nomor 1, Juli 2021 
pilgrims to understand what is being conveyed and played out in practice directly related to the series of pilgrimages for the congregation. ${ }^{27}$

5. The cleric arranges of the content for the Hajj rituals in a systematic and scheduled manner based to the knowledge needs of the pilgrims that supervises so as to motivate prospective pilgrims to join the KBIHU he leads because it gives trust to the community in an authentic way.

\section{Figures of Kyai in Hajj Guidance}

The second finding after guidance that is easily understood by the pilgrims is the figure of the Kyai. In organizing the hajj pilgrimage that is an urgent matter and needs special attention for the leaders. ${ }^{28}$ The figure of a leader in the minds of the general public becomes a point for deciding on beliefs, decisions to choose, decisions to follow, and so on. This happens because Kyai is a community figure who is considered pious in solving problems in the midst of society.

This strategy is indirectly a strategy in the leadership of the Kyai in providing guidance for the pilgrimage for the community, which then has implications for the KBIHU market he leads. The community believes in not only because of the special figure but also because of the management that is implemented in guiding the pilgrims. ${ }^{29}$

Based on the findings above, the emergence of Kyai figures in guiding these pilgrims is based on indicators of specific research findings, including of:

\section{Friendly service}

Kyai provides guidance services for pilgrims with a friendly attitude. The differences in the characteristics of the pilgrims who follow the guidance of the Hajj rituals are faced with an attitude of wisdom, calm, yielding, and

\footnotetext{
${ }^{27}$ Moh \& Dela Maghfirah Kamila Rifa'i.

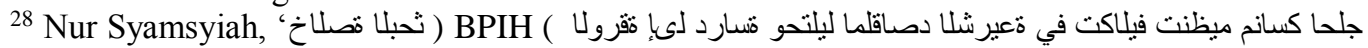

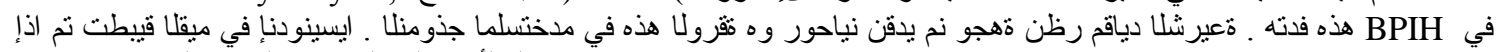

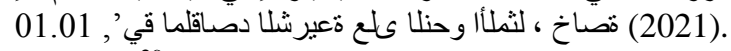

${ }^{29}$ Lia Fadillah, 'Strategi Dan Manajemen Travel Haji Dan Umroh ( Studi Analisis Persaingan Travel Haji Dan Umroh Kota Medan Dalam Pelayanan Dan Kualitas Untuk Meningkatkan Jumlah Konsumen )', Al-Muamalat Jurnal Hukum Ekonomi Syariah, IV.1 (2018), 1-24.
} 
taking care of each other's feelings. The services provided and prioritized by the Kyai have positive implications for pilgrims and prospective pilgrims.

This finding is balanced with the findings of Abdul Aziz al-Barqy's research on one of the leadership strategies, namely the courtesy of a leader which has good implications for the institution it manages. There is a connection even though the words are not the same, namely between the friendliness found by the researcher and the courtesy that is expressed. However, the point is that the Kyai prioritizes this hospitality in dealing with congregations whose characteristics are different.

There are several positive indicators that the researchers can put forward in this article:

a. Hajj guidance services always provide a sense of satisfaction for pilgrims, both in Indonesia and in Mecca and Medina. Such conditions are gradually conveyed to many people who get information from pilgrims who have undergone a series of worship with the Kyai. The point is marketing which used word by word was carried out by them to get guidance from Kyai and participating in KBIHU Nurul Haramain Kraksaan Probolinggo. ${ }^{30}$

b. Materialized solutions in developing problems (Problem solution) effectively and efficiently. The problems that occur are not prolonged and have negative implications for everything. All input and inspiration of the congregation that is conveyed in various meeting forums and even during meetings every ritual activity is accommodated and handled by the Kyai together with KBIHU Nurul Haramain management and experienced parties so as to produce the best solution for the pilgrims who are served.

c. Kyai's friendliness in providing guidance and services for the pilgrimage is a top priority in protecting the congregation with the aim that what they are doing is easy to understand, through perseverance, sincerity,

${ }^{30}$ Nuriawati, 'Pemanfaatan Media Sosial Sebagai Pemasaran Dalam Bisnis Syariah', Izzi (Sekolah Tinggi Ekonomi Dan Bisnis Islam Badri Mashduqi), 1.1 (2021), 42-54.

Tribakti: Jurnal Pemikiran Keislaman

Volume 32, Nomor 1, Juli 2021 
and diligence for pilgrims of different characters. This is a relevant strategy conveyed by Abdul Aziz al-Barqy in his research, and it is a particular concern to leaders in various organizations, especially Hajj and Umrah guidance organizations.

\section{Kyai facilitates the needs of pilgrims}

The second indicator of facilitation for congregation needs is the Kyai's leadership strategy, namely a figure. Kyai always pay special attention in providing guidance and this has implications for the trust and motivation of the community to jointly participate in KBIHU guidance led by the Kyai.

There are 2 sub-themes of Kyai's facilitation for the pilgrims supervises that can be done in increasing the confidence and volume of pilgrims from time to time, namely as follows:

a. Any affairs from the smallest to the big ones can be served by the kyai with ease, which are related to administration or travel documents such as making passports, visas and so on.

b. All matters that can be troublesome for the congregation are planned so that they can be handled easily before the pilgrimage runs smoothly. Not all pilgrims understand the Hajj rituals even though guidance has been carried out in the country for 12 times. Thus, not all of them are accustomed to traveling abroad. This became a difficulty for the congregation and was anticipated by the Kyai as part of the alacrity of the guidance service for the pilgrims so that it had implications for the realization of satisfaction.

This finding is not found in al-Barqy's findings which explain assertiveness, courtesy, intimacy, togetherness, and equality in office. So, the findings in this study become new things to pay attention to in guiding pilgrims today and future specifically. 


\section{Conclusion}

The results of this research explain that the leadership strategy of the kyai in the haj pilgrimage in order to increase the volume of the pilgrims consists of 2 strategies in each indicator. First, a service strategy that is easy to understand by implementing Hajj exercises or rituals 12 times in 1 year, collaborating with experienced and professional travelers to meet the needs of the community to go for Hajj, conducting Hajj pilgrimage practices directly led by Kyai and professionals who is involved as a guide, direct guidance from home to the holy land of Mecca and Medina, and Kyai arranges the Hajj rituals systematically scheduled according to the knowledge needs of the pilgrims. The two strategies of figures that appear in the Kyai consist of $2 \mathrm{sub}$ indicators, namely friendly service, and excellent facilitation by the Kyai for the congregation from in the country to the holy land of Makkah and Medina.

If the researcher illustrated the findings of this study in a flowcharct format, the Kyai's leadership strategy which has implications for the volume of pilgrims joining the KBIHU they lead is as follows:

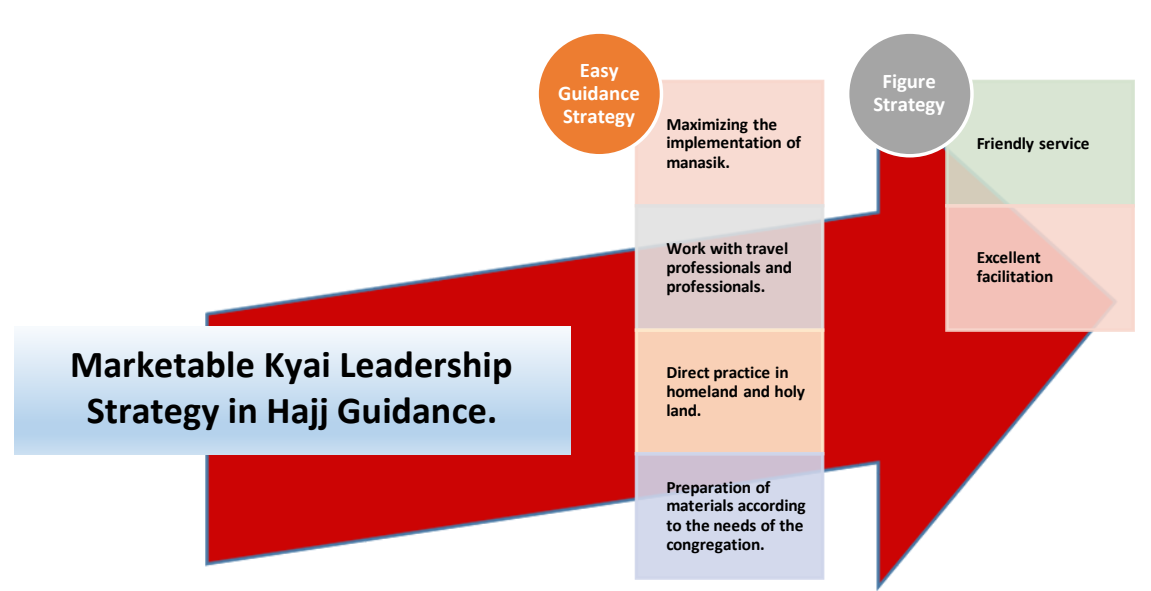

Figure 2. Marketable Leadership Strategy in the Hajj Guidance.

Based on the research findings above, it is necessary for pilgrims and umrah travel businessmen to pay attention to the findings that the researchers have presented in this manuscript so that later they can develop their leadership in the hajj pilgrimage effectively and efficiently. Of course, these findings must be relevant to the conditions of the respective KBIHU in various places. Thus, it is hoped that new leadership strategies will emerge in increasing quality guidance Tribakti: Jurnal Pemikiran Keislaman Volume 32, Nomor 1, Juli 2021 
and of course have implications for increasing the volume of pilgrims in the future.

\section{Bibliography}

Al-karim, Lukman, 'Gaya Kepemimpinan Kyai Lukman Al-Karim Dalam Pengembangan Lembaga Pendidikan Islam ( Studi Kasus Di Pondok Pesantren Bahrul Maghfiroh Malang )', 15 (2015), 497-518

Arifin, Zaenal, and Moh. Turmudi, 'Character of Education in Pesantren Perspective: Study Of Various Methods of Educational Character at Pesantren In Indonesia, Tribakti: Jurnal Pemikiran Keislaman, 30 (2019), 335-48

Soliha, Euis \& Hersugondo. Kepemimpinan Yang Efektif Dan Perubahan Organisasi, Fakultas Ekonomi Universitas Stikubank Semarang (2008)

Fadillah, Lia, 'Strategi Dan Manajemen Travel Haji Dan Umroh ( Studi Analisis Persaingan Travel Haji Dan Umroh Kota Medan Dalam Pelayanan Dan Kualitas Untuk Meningkatkan Jumlah Konsumen )', Al-Muamalat Jurnal Hukum Ekonomi Syariah, IV.1 (2018), 1-24

Hadi, M. Sabiq Al, 'Rekonstruksi Pemahaman Yang Keliru Tentang Kewajiban Dan Keutamaan Haji Dan Umroh', Al-Iqtishod: Jurnal Ekonomi Dan Bisnis Islam, 01.01, 65-84

Irawan, Wahyu Dwi, 'Analisis Kualitas Pelayanan Dalam Upaya Meningkatkan Loyalitas Pelanggan CV. Cahaya empat pilar banjarmasin' (Universitas Islam Kalimantan MAB, 2020)

Kifli, Dzul, 'Manajemen Pelayanan Jamaah Haji Dan Umrah Pt. Patuna Tour Dan Travel', Skripsi, 2010, 1-90

Kurniati, Mia, Miftahus Surur, and Ahmad Hafas Rasyidi, 'Peran Kepemimpinan Kyai Dalam Mendidik Dan Membentuk Karakter Santri Yang Siap Mengabdi Kepada Masyarakat', Al-Bayan: Jurnal Ilmu Al-Qur'an Dan Hadist, 2.2 (2019), 194-203 <https://doi.org/10.35132/albayan.v2i2.80>

Lestari, Pusti, Dadang Kuswana, and Yuliani Yuliani, 'Strategi Pelayanan Prima Kelompok Bimbingan Ibadah Haji Terhadap Calon Jamaah Dalam Meningkatkan Bimbingan Kualitas Ibadah Haji', Tadbir: Jurnal Manajemen Dakwah, 1.3 (2016), 258-74 <https:/ / doi.org/10.15575/tadbir.v1i3.139>

Ltda., Sandoz do Brasil Ind. Farm., Strategi Peningkatan Pelayanan Jamaah Haji KBIH Muhammadiyah Palembang, Journal of Chemical Information and Modeling, 53.9 (2015), 1689-99

Nezhad Haj Ali Irani, Farhad, Mohammad Reza Noruzi, Emmanouil F. Papavasileiou, Sean T. Lyons, O. C. Ferrell, Dana E. Harrison, and others, Procedia - Social and Behavioral Sciences, IV.2 (2017), 29-38

Nurfalah, Ridwan Nurfalah, Syamsuddin RS, and Arif Rahman, 'Strategi Pimpinan Dalam Optimalisasi Rekrutmen Jamaah Haji', Tadbir: Jurnal 
Manajemen Dakwah, $\quad 2.3 \quad$ (2017), $\quad 309-28$

<https:/ / doi.org/10.15575/tadbir.v2i3.567>

Nuriawati, 'Pemanfaatan Media Sosial Sebagai Pemasaran Dalam Bisnis Syariah', Izzi (Sekolah Tinggi Ekonomi Dan Bisnis Islam Badri Mashduqi), 1.1 (2021), 42-54

Pitoy, Vanesha, Altje Tumbel, Maria Tielung, Jurusan Manajemen, and Fakultas Ekonomi, Analisis Strategi Bersaing Dalam Persaingan Usaha Bisnis Document Solution ( Studi Kasus Pada PT . Astragraphia, Tbk. Manado )', 16.03 (2016), 302-12

Pratiwi, Ika Ari, Sekar Dwi Ardianti, and Moh. Kanzunnudin, Peningkatan Kemampuan Kerjasama Melalui Model Project Based Learning (PJBL) Berbantuan Metode Edutainment Pada Mata Pelajaran Ilmu Pengetahuan Sosial', Refleksi Edukatika: Jurnal Ilmiah Kependidikan, 8.2 (2018) <https:/ / doi.org/10.24176/re.v8i2.2357>

Ratih, Inayah Swasti, 'Strategi Bisnis Syariah Dalam Menghadapi Pandemi Covid-19', IZZI, 1.1 (2021), 1-18

RI, Kementerian Agama, Keputusan Menteri Agama Tentang Penetapan Kouta Haji 2020. Jakarta, 2020

Ridho, Zainur, 'Pengelolaan Keungan Dana Haji Di Masa Pandemi Covid-19', Haramain, 01.01 (2021), 1-27

Rifa'i, Moh., Community Empowerment (Pemberdayaan Masyarakat Dalam Meningkatkan Mutu Pendidikan), Kraksaan Probolinggo: CV. Mandiri Probolinggo, 2017

Rifa'i, Moh. \& Abd. Adhiem, Manajemen Koperasi Ritel Pondok Pesantren (Seni Tata Kelola Praktis Koperasi Ritel), raksaan Probolinggo: CV. Mandiri Probolinggo, 2018) <https://doi.org/9786025060182>

Rifa'i, Moh \& Dela Maghfirah Kamila, Strategi Layanan Dalam Meningkatkan Kepuasaan Jamaah Haji', Haramain, 01.01 (2021), 1-11

Sulaiman, Sulaiman, 'Kepuasan Jamaah Haji Terhadap Pelayanan KBH Di

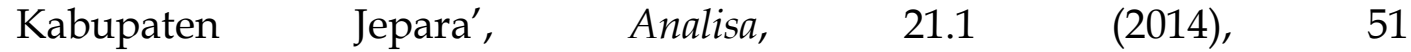
<https://doi.org/10.18784/analisa.v21i1.27>

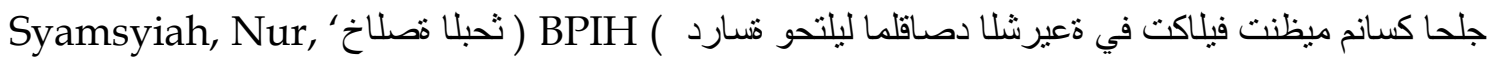

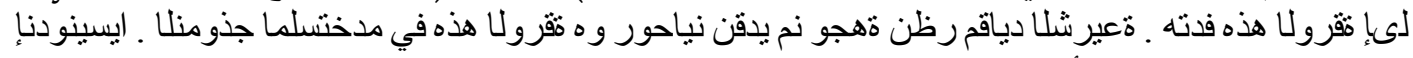

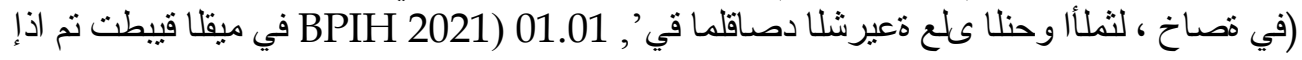

Velasquez-Valencia, Alexander, רלה מזלי, Saúl Dezzeo, Nelda, Flores, Sergio Zambrano-martínez, Elisa. Rodgers, Louise \& Ochoa, De Flora, and others, 'No Title', Interciencia, 489.20 (2018), 313-35

Widyarini, 'Manajemen Kelompok Bimbingan Ibadah Haji ( KBIH )', Jurnal Ekonomi Dan Bisnis Islam, Eksibisi, VII.2 (2013), 165-66 
Yusuf, Muhammad, 'Haji Dalam Al-Qur'an, Hadis Dan Pengalaman Muslim', 2008 